体力に及ほす「朝鮮人荡」摄取の影䉂について

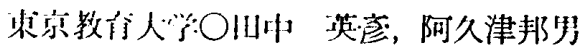
小原 凯文

東洋において古来上り，いわゆる朝鮮人落（Panax Ginseng）が保健ならびに治療に用いられているが，ま た，作力の強化にも効果があるといわれている。 しか し, 従米の生理学的あるいは蓧理学的研究も，この薬物 成分の生理的作用については，明らか炕していない。

本研究は，いわゆる体力に対し，どのような奻果を与 えるかを確め，さらに，その生理的機構を追究しょ5と したものである.

同一の被験者に，薬物を投与した場合と，投与しない 場合について，運動中及び運動休止後の呼吸・循㱬機能 について測定を行ない，この薬物の運動に対する影慗を みた。

自転車エルゴメーターによる比較的短時間に終る全力 的運動を行なつた場合には，投与例と対照例との閒に， とくに明確な相違は認め難い。

トレット゚ミルによる15 分開疾走を行なつた場合には，
投卡・対照の閏に，呼吸・循環成能に比較的明らかな相 違が琶められる。すなわち，投占例に打いては，心拍数 ・呼政数などの運動に伴う增加荠が，刘照にくらべて少 く，また，運動休止後においては，そ机らの四復時間 は，投与した場合には短かくなる㖽向がみられる。また 酸素負传・酸素摄取量・酸素需要量・酸素眽などについ ても投与例の方が此校的少く, さらK, RMR の値む小 さい，要するに，全般として，運動時において代謝の低 下がこの薬物によつてもたらされるとみられる。また， この薬物は，瞬発力・筋力などょりも，いわゆる持久力 に影響を与えるものと考えられる。

しかし，本研究では，実験例数が少なく，また薬物の 投与の諸条件，環境条件，薬物成分の抽出法など，実験 条件が十分とはいえないので，確定的なことは未だいい 難い，また，この莧物の生理的機構については，今後の 組識化学的な立場による考察をまたなくてはならない

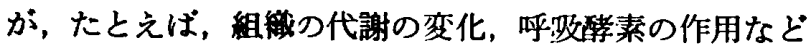
に対する本薬物の影䇾を追及することによつて，体力に 対する奻果の機構の解明に近つくと思われる.

\section{本学一般学生の身畏・体苴・肺活田の平均值および相 威䦷保について}

近畿大学○松本 晃雄, 森脇 勤
畑 茪彰, 武田 犆三
高场大志郎

\section{1. 研究の目的}

同一年令における肺活量と身長, 体重の相関はどらら が深いか，といらことが第1であり，次は身長，体重， 肺活量の平约値は本学学生において各種の標準值に対し ていかなる位膡を占めるかは指導上重要であると考え， 平素实施している身体諸計資料より導入しょらとしたこ とである.

\section{2. 拥查方法}

1966 作 4 月入学生満 18 才男子について無差別に 700 人を刘象とし，直立身長，100kg バネ秤り体重，TKK 6000cc 肺活量計に上り湘定し 比較数值は，大学保体協 議会A- 文部省体有局 1965 年B. 日本私立短大資料1965 年C. 大阪工大資料 1964 年D. その他を使用した.

\section{3. 結果と考寮}

（1）身長・体重・肺活量の平沟值についての検討 身長および体重と肺活量の相関保数を考える場合，そ の基本として各々の平均值について簡単に検討を加党，
前記 $\mathrm{A} \cdot \mathrm{B} \cdot \mathrm{C} \cdot \mathrm{D}$ と比较してみると, 大体要約して次の ことがいえる. 身長平均 $168 \pm 5.6 \mathrm{~cm}$ に対し， $A=167$ cm, B $=166.34 \pm 6.29, \quad \mathrm{C}=166.55 \pm 5.44, \mathrm{D}=167.58 \pm$ 5.36 で身長は大体平均して余り劣つていない，体重で は本学平沟 $59 \pm 6.8 \mathrm{~kg}$, 前記 $\mathrm{A}=56-58, \mathrm{~B}=56.44 \pm$ $6.12, \mathrm{C}=57.3 \pm 6.3, \mathrm{D}=56.77 \pm 5.99$ で，体重では標準 よりすぐれている．肺活量は $3870 \pm 523 c c$ であつたが， $\mathrm{D}=4178 \pm 536$ で他の標準でる本学は劣るようである.

肺活量指数 Hutchinson index は24.29 で大体普通で ある. 身長体重ハシランスは平均值で $61.2 \mathrm{~kg}$ 体重である から体重平均値に近似しているといえる。

（2）身長と体重の肺活量との相関保数の比較 本来の指数は体表面と肺活量の関係であるが，ここで は Hutchinson と Dreyer の指数で検討した。 すなわ ち，肺活量と身長の相関倸数は+0.4186であり，肺活 量と体重では，十0.4294 となり，18才男の場合何れも 大きい羑はないといえる，年令が 18 才といら場合には 身長体重共に 集中的で平均值を中心飞チラバリは少な く, 此較数值よりむしろ本学生の方が優れているが，一 機能である肺活量になるとむしろ標準值より劣るといら 傾向にあつて，相関係数より機能の指導面に重要さを発 見した。 